\title{
Cottage Food in Florida ${ }^{1}$
}

\section{Sarah M. Ellis, Jennifer Hagen, and Matthew D. Krug ${ }^{2}$}

This document is one in a "Florida Food Entrepreneur" series, which seeks to assist new and established food entrepreneurs by providing information on topics relevant to food-based businesses.

In Florida, individuals can manufacture, sell, and store specific types of cottage food products in their primary home kitchen in accordance with Florida Statute 500.80. Cottage food operators are not required to obtain a license or permit, and these operations are not inspected by any state government entity.

\section{Sales and Marketing}

Cottage food businesses must not exceed $\$ 50,000$ in gross sales annually. Products must be sold direct to consumer and cannot be sold wholesale or across state lines. Cottage food operators may advertise, sell, and accept payment over the internet; however, products cannot be delivered through the mail. Products may be sold at farmer's markets, pop-up markets, flea markets, and roadside stands (provided there are no other food items at the stand that require a food permit).

\section{Allowable Foods}

Foods manufactured under the cottage food law are limited to products that are considered a low risk for causing foodborne illness. Many products are not allowed to be manufactured under the cottage food law because they require time/temperature control for food safety to limit pathogenic microorganism growth or toxin formation. Examples of products allowed and prohibited to be sold as cottage foods are found in Table 1.

\section{Labeling Requirements}

Cottage food operators may only sell allowed products that are prepackaged and labeled for individual sale. The affixed product label is required to include the following information:

- Name and physical address of the cottage food operation

- Name of the product

- Ingredient list for the product in descending order by weight

- Net weight or net volume of the product

- Allergen information as required by federal law

- Must identify if any of the following are in the product:

- Milk

- Eggs

- Wheat

- Peanuts

- Soybeans

- Fish (including shellfish, lobster, crab, or shrimp)

- Tree nuts (almonds, pecans, walnuts, etc.)

1. This document is FSHN20-55, one of a series of the Food Science and Human Nutrition Department, UF/IFAS Extension. Original publication date February 2021. Visit the EDIS website at https://edis.ifas.ufl.edu for the currently supported version of this publication.

2. Sarah M. Ellis, family and consumer sciences agent I, UF/IFAS Extension Citrus County; Jennifer Hagen, family and consumer sciences agent I, UF/IFAS Extension Lee County; and Matthew D. Krug, state specialized agent II, UF/IFAS Southwest Florida Research and Education Center; UF/IFAS Extension, Gainesville, FL 32611.

The Institute of Food and Agricultural Sciences (IFAS) is an Equal Opportunity Institution authorized to provide research, educational information and other services

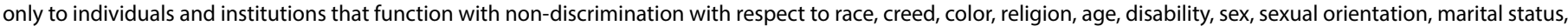

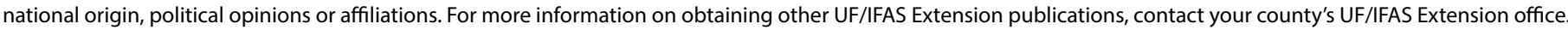
U.S. Department of Agriculture, UF/IFAS Extension Service, University of Florida, IFAS, Florida A \& M University Cooperative Extension Program, and Boards of County Commissioners Cooperating. Nick T. Place, dean for UF/IFAS Extension. 
- Cottage food operation statement printed in at least 10-point font in a contrasting color to the label background: "Made in a cottage food operation that is not subject to Florida's food safety regulations."

Additionally, if any nutritional claim is made, the label must include the appropriate information specified by the federal Food and Drug Administration. To learn about nutritional food claims and label requirements, visit https://www.fda.gov/food/food-labeling-nutrition/ label-claims-conventional-foods-and-dietary-supplements.

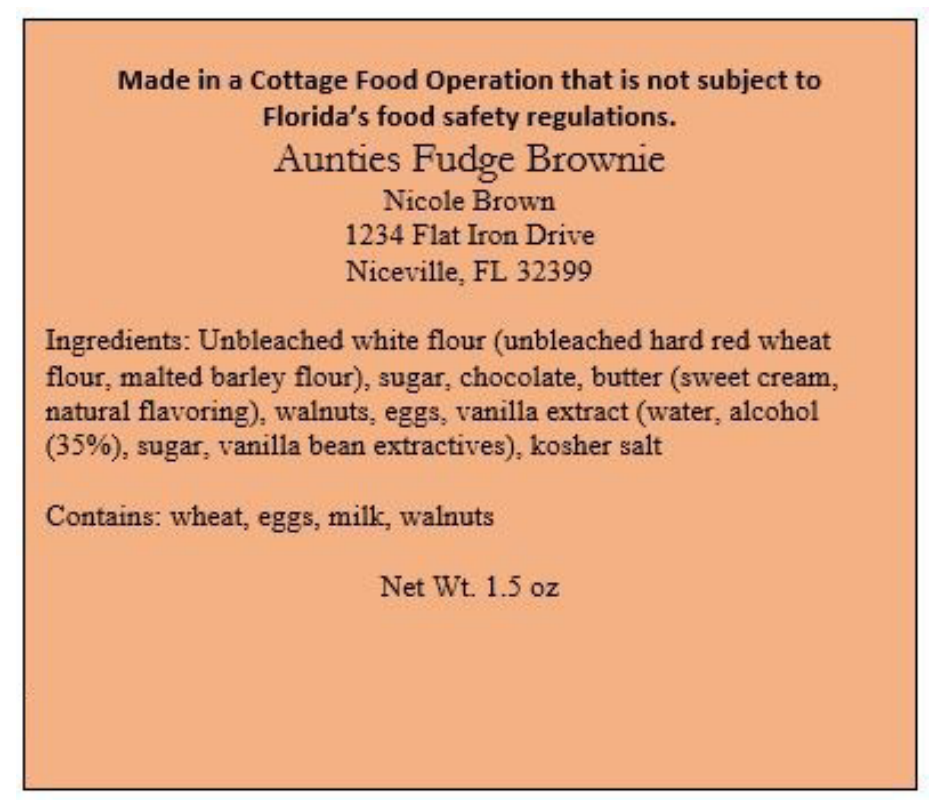

Figure 1. Example Cottage Food Label

\section{Frequently Asked Questions}

Do I need to apply for a local business tax account or home occupational license as a cottage food operator? Anyone wishing to start a food-related business should contact their local tax collector and inquire as to whether they need to collect taxes. While many food and grocery items are exempt from tax, some food products are not tax exempt.

What happens if someone files a complaint against me? Even though cottage food operations are not inspected by any state government entity, if a complaint is received, the Florida Department of Agriculture and Consumer Sciences (FDACS) will investigate. Furthermore, if FDACS finds the operation is in violation, the operation may be fined.

\section{Can I make pumpkin butter?}

No. Pumpkin butter is considered a potentially hazardous food because it is a low-acid food that may support the growth of harmful bacteria and cause a foodborne illness.

\section{Can I make pet food or treats?}

No. The cottage food law only applies to human food. Pet food is regulated by state and federal laws.

My friend has a cottage food business, but my wedding venue requires all vendors to have a food license. Can a venue or market require a license?

Yes. Even though the entity may meet the requirements of a cottage food operation, some venues or other direct sales markets may require vendors to have additional licensing or food protection manager's certification.

\section{Can I sell my cottage food products from a convenience store?}

No. A permitted commercial food establishment or mobile food vendor cannot sell foods from an unapproved source, including cottage foods.

Can my county or city prevent or restrict me from having a cottage food operation?

Yes. Local governments may have policies that restrict cottage food operations.

Can I grow my own produce, such as pumpkins, to can and use them later for baked goods?

No. Home-canned products cannot be used. Commercially processed canned fillings such as canned pumpkin must be used.

\section{Further Resources}

Florida Department of Agriculture and Consumer Services (FDACS) Cottage Food Operations Guidance: https://www. fdacs.gov/content/download/70108/file/Cottage-FoodBrochure.pdf

Florida Statute 500.80 (Cottage Food Operations): http:// www.leg.state.fl.us/statutes/index.cfm?App_mode=Display_ Statute\&URL $=0500-0599 / 0500 /$ Sections $/ 0500.80$.html 
Table 1. Examples of products allowed and prohibited by the cottage food law.

\begin{tabular}{|l|l|}
\hline \multicolumn{1}{|c|}{ Allowed Cottage Foods } & \multicolumn{1}{c|}{ Prohibited Foods } \\
\hline Biscuits & $\begin{array}{l}\text { Baked goods that require any refrigeration (custard, cream cheese icing or } \\
\text { filling, etc.) }\end{array}$ \\
\hline Candies and confections & Canned fruits, vegetables, chutneys, garlic dip, and hummus \\
\hline Cereals, granola, and trail mixes & Canned pickled products (relish, pickles, etc.) \\
\hline Coated or uncoated nuts & CBD or hemp items \\
\hline Cookies, cakes, and pastries & Cut fresh fruits and vegetables \\
\hline Dry herbs, seasonings and mixtures & Eggs \\
\hline Fruit jams, jellies, and preserves & Fish or shellfish products \\
\hline Fruit pies & Focaccia style breads with cheeses or vegetables \\
\hline Homemade pasta & Fresh or dried meat or meat products (jerky) \\
\hline Honey & Ice and ice products \\
\hline Loaf breads and rolls & Milk and dairy products \\
\hline Nut butters & Raw seed sprouts \\
\hline Popcorn, popcorn balls & Salsa, BBQ sauce, ketchup, mustard \\
\hline Roast coffee beans (whole or ground) & Syrups (including elderberry) \\
\hline Vinegar and flavored vinegars & Vegetable butters and jellies \\
\hline
\end{tabular}

